\title{
Improving Knowledge of Sports Games Training Programs for Junior High School Physical Education Teachers in the Purwokerto Region
}

\author{
Didik Rilastiyo Budi ${ }^{1}$, Topo Suhartoyo² \\ 1,2 Jenderal Soedirman University \\ Email: 1didik.rilastiyo.budi@unsoed.ac.id \\ d. \\ https://doi.org/10.36526/gandrung.v2i1.1161
}

\begin{abstract}
The preparation of training programs for sports achievement coaching activities in schools, mainly Junior High Schools (SMP) through the Sports Extracurricular program, is an essential factor that coaches and mentor teachers must pay attention to so that the coaching process can run well. The purpose of this Community Service (PKM) activity is to increase the knowledge and skills of coaches and sports extracurricular coaches in preparing training programs. The activity method used is through training, mentoring and activity evaluation. The training was attended by 20 sports extracurricular coaches and teachers in SMP throughout Purwokerto. The training and mentoring results showed that in the initial test, it was found that most of the participants did not understand the preparation of an exercise program so that they were not able to compile an exercise program properly. In contrast, the final test carried out at the end of the activity showed an increase in the participants' understanding of a sports training program's preparation. The participants training participants can compile a game sports training program that will be implemented in school extracurricular activities.
\end{abstract}

Keyword: Training, Training Programs, Coach and Teachers, Junior High Schools (SMP)

\section{Pendahuluan}

Olahraga yang dilaksanakan disetiap jenjang pendidikan dari tingkat Sekolah Dasar (SD), Sekolah Menengah Pertama (SMP) dan Sekolah Menengah Atas (SMA) memiliki tujuan untuk mengembangkan potensi yang dimiliki oleh siswa. Olahraga pendidikan atau pendidikan jasmani memiliki tujuan untuk mengembangkan potensi siswa dari aspek kognitif, afektif dan keterampilan (psikomotor) (Budi, Hidayat, et al., 2019; Setiawan et al., 2020). Dalam upaya mewujudkan tujuan tersebut, setiap sekolah melaksanakan proses pembelajaran pendidikan jasmani dalam dua kegiatan, yaitu melalui program intrakurikuler dan ekstrakurikuler olahraga.

Pelaksanaan pembelajaran pendidikan jasmani pada kegiatan intrakurikuler dilakukan dengan siswa mengikuti program pembelajaran secara rutin dan terjadwal dengan berbagai materi yang harus dilaksanakan oleh siswa. Materi pembelajaran pada pendidikan jasmani terdiri dari olahraga permainan, olahraga beladiri, kebugaran jasmani, senam dan atletik (Budi, Kusuma, et al., 2019; Qohhar \& Pazriansyah, 2019; Yani \& Hasri, 2020). Berbagai materi olahraga yang beragam dapat membuat siswa memiliki pengalamam gerak olahraga yang bervariasi sebagai dasar untuk pemanduan dan 
GANDRUNG: Jurnal Pengabdian Kepada Masyarakat ISSN: 2721-6136 (Online)

pengembangan bakat olahraga pada siswa diusia selanjutnya.

Selian kegiatan intrakurikuler, pelasanaan program olahraga dijenjang pendidikan SD, SMP dan SMA juga dikembangkan melalui kegiatan ekstrakurikuler. Ekstrakurikuler merupakan kegiatan pembelajaran diluar kegiatan intrakurikuler yang diselenggarakan untuk pembentukan karakter pada siswa (Kamnuron et al., 2020; Subarkah et al., 2017). Lebih lanut Sayfei et al. (2020) dan Suparyo (2017) menjelaskan tujuan diselenggarakannya kegiatan ekstrakurikuler bidang olahraga diharapkan dapat memberikan pengaruh terhadap minat, bakat dan potensi yang dimiliki oleh siswa.

Berdasarkan penjelasan tersebut maka, kegiatan ekstrakurikuler olahraga di sekolah menjadi hal yang penting dalam mengembangkan potensi siswa dalam bidang olahraga, sehingga dapat meningkatkan prestasi non akademik yang dicapai oleh sekolah melalui berbagai pertandingan olahraga tingkat pelajar. Untuk mendukung terlaksanakannya program ektrakurikuler olahraga yang baik, maka setiap sekolah membentuk berbagai unit kegiatan ektrakurikuler olahraga sebagai tempat berlatih dan mengembangkan potensi olehaga bagi siswa. Salah satu cara untuk menumbuhkembangkan prestasi olahraga dilembaga pendidikan, pada setiap jalur Pendidikan dapat dibentuk unit kegiatan olahraga (UU SKN, 2005).

Pembentukan unit kegiatan ekstrakurikuler olahraga di sekolah memiliki peran penting dalam proes pembinaan prestasi olahraga di sekolah dalam upaya pencapaian prestasi di multi event olahraga, seperti Pekan Olahraga Pelajar Daerah (POPDA), Pekan Olahraga Pelajar Nasional (POPNAS) dan Olimpiade Olahraga Siswa Nasional (O2SN). Untuk dapat menjaga keberlangsungan kegiatan ektrakurikuler olahraga sekaligus sebagai sarana untuk mencapai prestasi, maka keberadaan seorang pelatih dan guru pembina ektrakurikuler olahraga yang kompeten menjadi salah satu faktor penting. Guru dan pelatih yang berkompeten dapat meengembangkan potensi siswa dengan baik melalui kegiatan ektrakurikuler olahraga untuk mampu bersaing memperoleh prestasi dibidang olahraga (Asnaldi, 2015; Indrayana, 2017).

Keberadaan pelatih atau guru pembina ektrakurikuler yang memiliki pengalaman dan pengetahuan mengenai program dan proses latihansangat dibutuhkan dalam mengembangkan program ektrakurikuler olahraga. Pengalaman dari seorang pelatih atau guru perlu didukung dengan pengetahuan mengenai penyusunan serta penerapan program latihan yang tepat kepada siswa sesuai dengan cabang olahraga masing-masing.

Berdasarkan diskusi yang telahdilakukan dengan ketua MGMP Guru Penjas SMP Kabupaten Banyumas dan Ketua MGMP Guru Penjas SMP se-Purwokerto, pelatihan atau seminar mengenai penyusunan program latihan olahraga bagi pelatih dan guru pembina ektrakurikuler olahraga di 
GANDRUNG: Jurnal Pengabdian Kepada Masyarakat ISSN: 2721-6136 (Online)

Purwokerto belum pernah dilakukan. Apabila terdapat pelatihan, maka lebih dikususkan kepada pelatih dibawah naunagan KONI kabupaten, dan tidak semua guru atau pelatih ektrakurikuler termasuk dalam agenda KONI tersebut, sehingga sebagai besar guru atau pelatih ektrakurikuler tidak dapat mengikuti kegiatan untuk megembangkan diri dalam penyusunan program latihan yang dapat diterapkan di sekolah.

Pelaksanan kegiatan Pengabdian Kepada Masyarat ini didasari dari fakta yang terjadi dilapangan bahwa: a) belum banyak pelatih dan guru pembina ektrakurikuler olahraga di SMP yang memahami cara penyusunan program latihan; b) Pelasanaan program latihan di ekstrakurikuler belum memiliki panduan yang dapat digunakan dalam proses latihan, c) pelatih dan guru pembina kegiatan ektrakurikuler belum mendapat pelatihan atau seminar mengenai cara menyusun program latihan, khususnya pada olahraga permainan.

Berdasarkan kondsi mengenai perlunya kegiatan pelatihan mengenai penyusunan program latihan olahraga bagi pelatih dan guru pembina ektrakurikuler olaharaga di SMP se Purwokerto maka pengabdi melakukan kegiatan pelatihan penyusunan program latihan olahraga permainan bagi pelatih dan guru olahraga SMP. Fokus utama dari tujuan kegiatan pengabdian ini yaitu untuk meningkatkan pemaham pelatih dan guru pembina ektrakurikuler dalam hal: a) Pentingya menyusun program latihan pada masing-masing cabang olahrga; b) Pelatih dan guru terampil dalam menyusun program latihan yang tepat; c) penerapan program latihan kedalam proses latihan di kegiatan ektrakurikuler.

\section{Metode}

Kegiatan Pengabdian Kepada Masyarakat (PKM) penyusunan program latihan olahraga permainan yang dilasanakan kepada pelatih dan guru pembina ektrakurikuler olahraga SMP di Purwokerto diikuti oleh 20 orang pelatih dan guru pembina ektrakurikuler. Tempat pelaksanaan kegiatan pelatihan yaitu di ruang serbaguna SMPN 2 Purwokerto Kabupaten Banyumas, yang dilaksanakan selama satu hari pada tanggal 26 September tahun 2019. Jadwal pekasanaan kegiatan pengabdian adalah seperti tertera pada Tabel 1 dibawah ini. 
GANDRUNG: Jurnal Pengabdian Kepada Masyarakat ISSN: 2721-6136 (Online)

Tabel. 1. Jadwal Pelaksanaan Kegiatan Pengabdian Kepada Masyarakat

\begin{tabular}{ccc}
\hline Hari Tanggal & Waktu & JenisKegiatan \\
\hline & $07.30-08.30$ & Persiapan dan Pembukaan \\
\cline { 2 - 3 } Kamis, 26 September 2019 & $08.30-12.00$ WIB & Pemaparanmateripelatihan dan diskusi \\
\cline { 2 - 3 } & $12.30-15.30$ WIB & Praktik penyusunan program latihan \\
\cline { 2 - 3 } & $15.30-16.30$ WIB & Evaluasi dan penutupan \\
\hline
\end{tabular}

Narasumber dalam kegiatan pelatihan ini yaitu dosen Jurusan Pendidikan Jasmani Fakultas IImuIImu Kesehatan Universitas Jenderal Soedirman dengan ketentuan sebagai berikut

1. Didik Rilasityo Budi, S.Pd., M.Pd. Menyampaikan materi penyusunan program latihan olahraga permainan net game (Tenis Lapangan) dan Bola Tangan.

2. Topo Suhartoyo, S.Pd., M.Or. Menyampaikan materi penyusunan program latihan olahraga Tenis Meja dan Sepakbola.

Pelasanaan kegiatan Pengabdian Kepada Masyarakat (PKM) dilaksanakan dengan tujuan untuk memberikan pelatihan kepada pelatih dan guru pembina kegiatan ektrakurikuler olahraga di SMP, sehingga pemahaman serta keterampilan pelatih dan guru dalam penyusunan program latihan olahraga dapat semakin meningkat. Kegiatan ini dilasanakan melalaui beberapa tahap, diantaranya:

1. Wawancara dengan Ketua MGMP Guru Penjas Kabupaten Banyumas dan Ketua MGMP Guru Penjas se Purwokerto mengenai kondisi dan kebutuhan pelatih dan guru dalam penyusunan program latihan olahraga di ektrakurikuler.

2. Melakukan perizinan kepada Kepala SMPN 2 Purwokerto untuk ketersediaan tempat dan peralatan pelaksanaan kegiatan Pengabdian.

3. Memberikan surat undangan kepada guru dan pelatih cabang olahraga di SMP se Purwokerto unduk dapat mengikuti kegiatan PKM.

4. Melakukan pelatihan kepada pelatih dan guru penmbina ektrakurikuler olahraga di SMP se Purwokerto, dengan terlebih dahulu melakukan tes awal mengenai pemahaman peserta tentang penyusunan program latihan olahraga, sebelum peserta mendapatkan pelatihan.

5. Melakukan pendampingan kepada peserta pelatihan menganai cara menyusun program latihan olahraga sesuai dengan cabang olahraga masing-masing.

6. Melakukan tes akhir kepada peserta mengenai pemahaman dalam penyusunan program latihan olahraga setelah mengikuti pelatihan.

7. Tahap evaluasi kegiatan secara keseluuhan yang dilakukan oleh tim pengabdi, SMPN 2 Purwokerto dan Ketua MGMP Guru Penjas sekaligus mendiskusikan kegiatan pada tahap selanjutnya. 
GANDRUNG: Jurnal Pengabdian Kepada Masyarakat ISSN: 2721-6136 (Online)

\section{Hasil dan Diskusi}

Pelaksanaan kegiatan dimulai dengan seluruh peserta melakukan absen kehadiran di meja yang telah disediakan oleh panitia. Kegiatan selanjutnya yaitu diawali dengan pembukaan kegiatan pelatihan oleh ketua panitia. Kegiatan pembukaan dapat dilihat pada Gambar 1 dibawah ini.

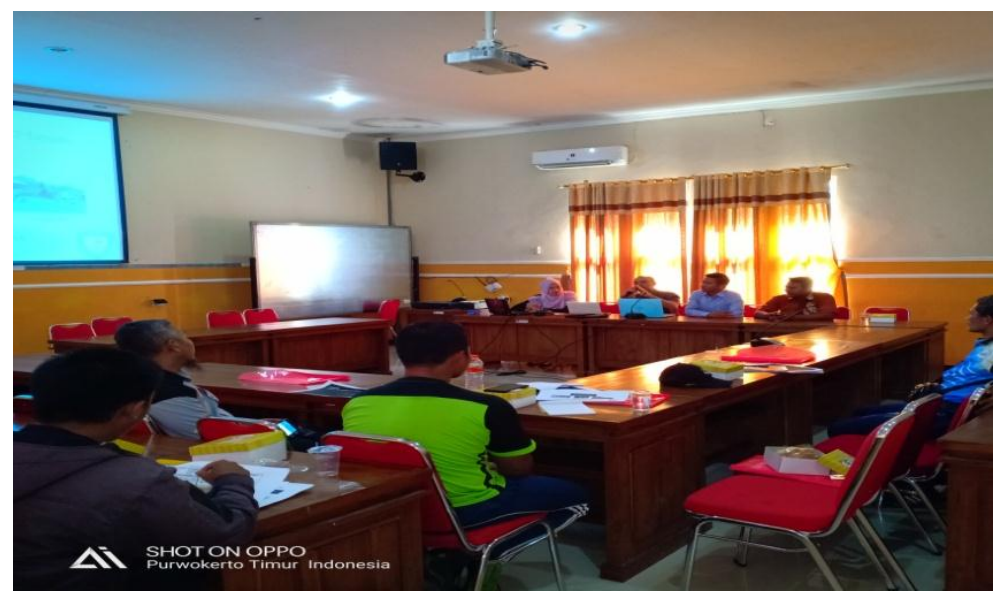

Gambar 1. Acara Pembukaan Pelatihan Penyusunan Program Latihan Olahraga

Pembukaan pelatihan penyusunan program latihan olahraga dilakukan oleh tim Pengabdian Kepada Masyarakat (PKM) Jurusan Pendidikan Jasmani Flkes Unsoed dan diikuti oleh seluruh peserta pelatihan yang terdiri dari pelatih dan guru pembina kegiatan ekstrakurikuler olahraga di SMP se Purwokerto.

Kegiatan selanjutnya yaitu penyampaian materi pelatihan mengenai penyusunan program latihan olahraga permainan yang disampaikan oleh tim pengabdi yang merupakan dosen olahraga dari jurusan Pendidkan Jasmani Fikes Unsoed Purwokerto, yang terlihat pada gambar 2 dibawah ini.

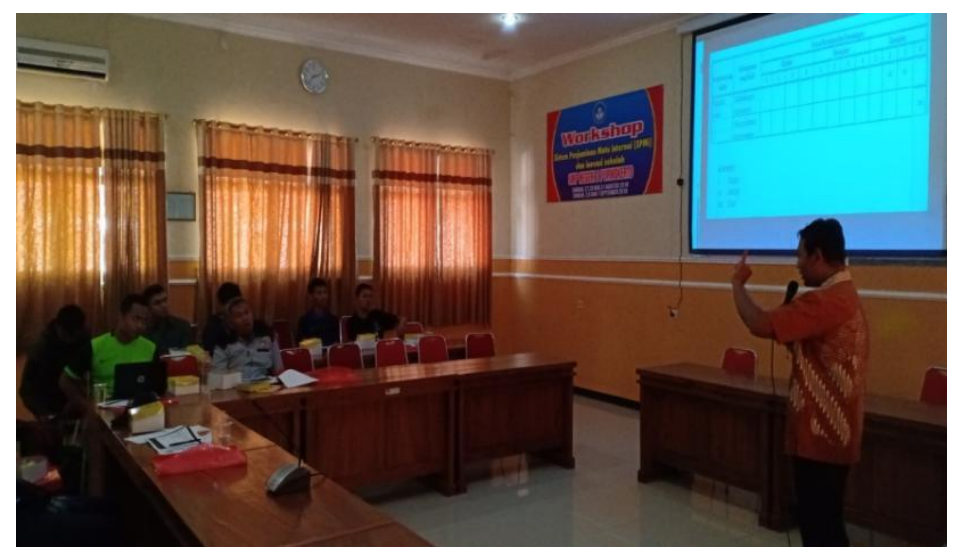

Gambar 2. Penyampaian Materi Pelatihan Penyususnan Progam Latihan Olahraga Permainan 
GANDRUNG: Jurnal Pengabdian Kepada Masyarakat ISSN: 2721-6136 (Online)

Penyampaian materi pelatihan dilakuan dengan metode presentasi oleh narasumber dan dilanjutkan dengan tanya jawab dari peserta. Metode ini membuat peserta seara aktif terlibat dalam proses kegiatan dan dapat mengembangkan pengetahuan peserta menegai penyusunan program latihan olahraga permainan. Tahap selanjutnya dilakukan pendampingan dalam penyusunan program latihan yaang dilakukan oleh peserta kegiatan, sehingga dapat diketahui tingkat pemahaman dan keterampilan masing-masing peserta dalam menyusun program latihan yang akan diterapkan di ektrakurikuler masing-masing sekolah. Rincian kegiatan dapat dilihat pada Tabel 2 dibawah ini

Tabel. 2. PelaksanaanKegiatanPengabdianKepada Masyarakat

\begin{tabular}{lcc}
\hline \multicolumn{1}{c}{ JenisKegiatan } & Waktu & Narasumber \\
\hline $\begin{array}{l}\text { Presentasi materi 1: Program latihan permainan net } \\
\text { game (TenisLapangan) dan Bola Tangan }\end{array}$ & $08.30-09.30$ WIB & DidikRilastiyo Budi \\
\hline $\begin{array}{l}\text { Presentasi materi 2: penyusunan program latihan } \\
\text { olahraga Tenis Meja dan Sepakbola. }\end{array}$ & $09.30-10.30$ WIB & Topo Suhartoyo \\
\hline Diskusi & $10.30-12.00$ WIB & Panitia dan Narasumber \\
\hline $\begin{array}{l}\text { Pendampingan penyusunan program latihan } \\
\text { sederhana }\end{array}$ & $12.30-15.30$ WIB & Narasumber dan peserta \\
\hline
\end{tabular}

Tahap terakhir yaitu dilakukan dengan pemberian tes akhir dan evaluasi kepada seluruh peserta untuk mengetahui tingkat keberhasilan kegiatan pelatihan, serta mengkur tingkat pemahaman peserta kegiatan mengenai penyusunan program latihan apkah mengalami peningkatan dari yang sebelumnya atau tidak. Alat ukur yang digunakan untuk mengetahui tingkat pemahan peserta yaitu dengan menggunakan angket mengenai program latihan yang dibuat oleh tim pengabdi sekaligus sebagai narasumber. Setelah ini maka kegiatan pelatihan ditutup dengan foto bersama antara panitia, tim pengabdi dan peserta, seperti terlihat pada gambar 3 dibawah ini.

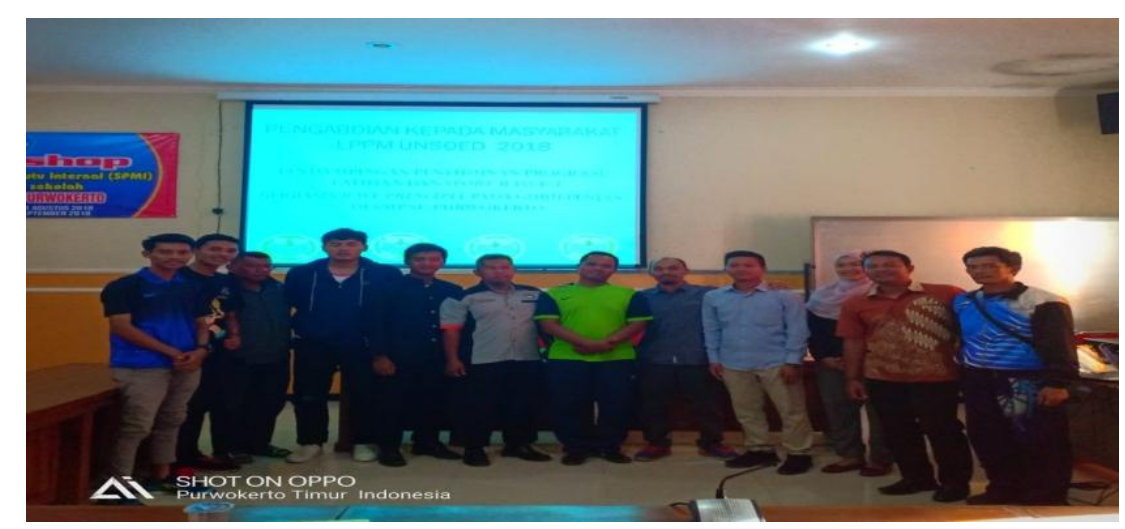

Gambar 3. Penutupan dan Foto Bersama

Volume 2, Number 1, Februari 2021| 78 Improving Knowledge of Sports Games Training Programs for Junior High School Physical Education Teachers in the Purwokerto Region 
GANDRUNG: Jurnal Pengabdian Kepada Masyarakat ISSN: 2721-6136 (Online)

Pelasanaan kegiatan Pengabdian Kepada Masyarakat (PKM) dengan sasaran utama pelatih dan guru pembina kegiatan ektrakurikuler di SMP se Purwokerto dalam pelatihan penyusunan program latihan olahraga permainan diperoleh hasil sesuai tertera pada Tabel 3 dibwah ini.

Tabel. 3. Hasil Tes Awal dan Akhir Pengetahuan Mengenai Penyusunan Program Latihan

\begin{tabular}{lccc}
\hline Tes Pemahaman Penyusunan Program latihan & N & Memahami & Belum Memamhami \\
\hline Tesa Awal & 20 & 9 & 11 \\
\hline Tes Akhir & 20 & 14 & 6 \\
\hline
\end{tabular}

Berdasarkan data yang diperoleh mengenai tingkat pemahaman mengenai penyusunan program latihan olahraga permainan diperoleh bahwa pada tes awal sebanyak 9 orang pelatih dan guru sudah memahmai mengenai program latihan dan cara menyusun program tersebut, 11 orang guru dan pelatih teridentifikasi belum memahami serta belum mampu menyusun program latihan olahraga permainan. Pada tes akhir, setelah peserta pelatihan mendapatkan materi dan pendampingan dalam menyusun program latihan, menunjukan hasil bahwa sebanyak 14 orang pelatih dan guru sudah mengalami peningkatan dalam pemahaman dan penyusunan program latihan olahraga, sedangkan sebanyak 6 orang pelatih dan guru belum secara maksimal untuk dapat memahami penyusunan program latihan.

Pelatih dan guru yang mengalami penignkatan dalam segi pemahaman dan penyusunan program altihan olahraga permainan dikarenakan pada saat pelaksanaan kegiatan mereka mengikuti setiap tahap dengan baik, sehingga materi yang disampaikan oleh naraumber dapat diaplikasikan secara optimal. Sedangkan ada sebagian kecil peserta yang belum mampu mengaplikasikan penyusunan proigram latihan dengan baik, hal ini dikarenakan peserta tersebut tidak mengikuti kegiatan dari awal hingga akhir karena ada beebrapa kepentingan di tempat kerja, sehingga hasil yang diperoleh juga kurang maksimal.

Berikut ini merupakan prosentase peningkatan pengetahuan dan keterampilan peserta pelatihan penyusunan program latihan olahraga dari tes awal dan tes ahir, yang terlihat pada gambar 4 dibaah ini. 
GANDRUNG: Jurnal Pengabdian Kepada Masyarakat ISSN: 2721-6136 (Online)

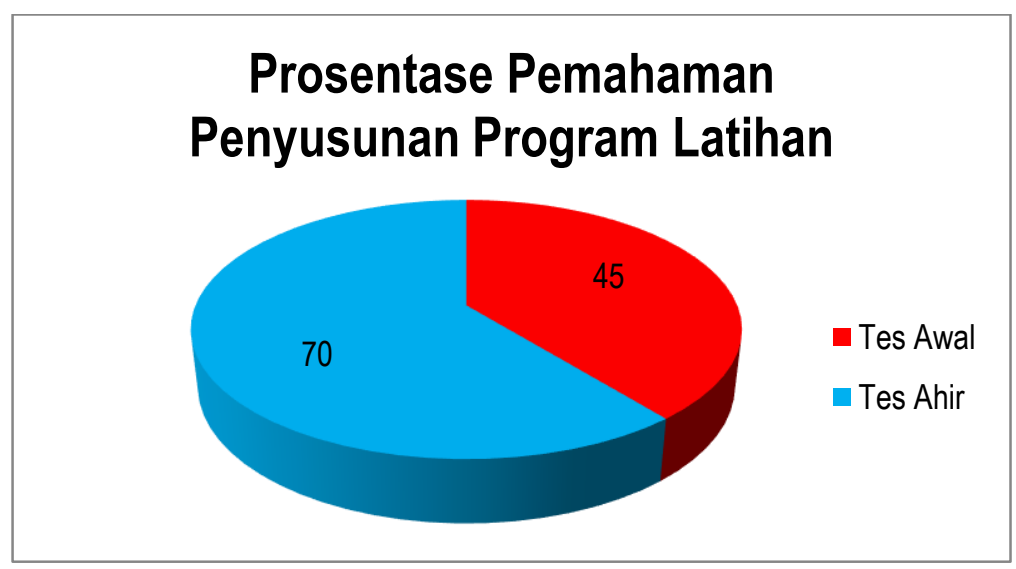

Gambar 4. Prosentase Pemahaman Penyusunan Program Latihan Peserta Pelatihan

Berdasarkan gambar diatas diketahui bahwa prosentase pemahaman pelatih dan guru SMP dalam menyusun program latihan olahraga di ektrakurikuler pada tes awal menunjukan sebesar $45 \%$ pelatih dan guru telah memahami cara menyusun program latihan, dan pada tes akhir terdapat peningkatan menjadi $70 \%$ pelatih dan guru telah memahami cara menyusun program latihan yang aka diterapkan di ektrakurikuler pada setiap cabang olahraga. Peningkatan pemahaman dan keterampilan dalam menyusun program altihan dari tes awal sebelum pelatihan ke tes akhir setelah pelatihan yaitu sebesar $35 \%$.

Program latihan yang disusun serta diterapkan oleh pelatih dan guru pembina ektrakurikuler olahraga di sekolah, khusunya pada tingkat SMP menjadi dasar dari proses pembinaan prestasi di lingkungan sekolah. Pembinaan prestasi olahraga di sekolah memerlukan perencanaan dan penerapan program latihan yang tepat, sehingga siswa dapat memaksimalkan potensi yang dimiliki (Budi, Syafei, et al., 2020; Harsono, 2017; Kusuma et al., 2019). Program latihan merupakan panduan yang akan dilakukan oleh pelatih dan guru pembina ektrakurikuler dalam menjalankan proses latihan kepada siswa.

Pentingnya pelatih dan guru memahami penyusunan program latihan yang tepat bagi siswa SMP yang masih dalam usia muda dapat membantu siswa untuk terhidar dari cedera karena proses latihan yang kurang tepat dan terlalu berat (overtraining). Cedera olahraga pada atlet pelajar, dapat dikurangi resikonya dengan menerapkan program latihan yang tepat dan disesuaikan dengan kondisi atlet (Hidayat et al., 2019; Syafei et al., 2020). Semakin kecil kemungkinan atlet usia pelajar mengalami cedera pada saat latihan maupun pertandingan, maka pada perkembangan selanjutnya dapat meningkatkan keterampilan dan prestasi olahraga yang dimiliki(Budi, Agustan, et al., 2020).

Hasil program PKM telah menunjukan bahwa pelatih dan guru pembina ektrakurikuler di SMP se Purwokerto menunjukan peningkatan pemahaman mengenai pentingnyapenyusunan program latihan, 
GANDRUNG: Jurnal Pengabdian Kepada Masyarakat ISSN: 2721-6136 (Online)

selain itu sebagian besar pelatih dan guru telah mampu membuat program latihan sebagai panduan dalam menjalankan program pembinaan di ektrakurikuler. Diharapkan dengan penerapan program latihan yang tepat, atlet dapat terhindar dari cdera dan mampu mencapai prestasi olahraga secara optimal dan berkelanjutan.

\section{Kesimpulan}

Berdasarkan hasil pengabdian yang telah dilaksanakan dapat disimpulkan bahwa melalui pelatihan penyusunan program latihan, pengetahuan dan pemahan pelatih serta guru pembina ektrakurikuler olahraga di SMP se Purwokerto dapat meningkat. Selain itu, pelath dan guru juga dapat menyusun perogram latihan secara sederhana sesui dengan cabang olahraganya masing-masing. Program pelatihan bagi guru dan pelatih cabang olahraga di ektrakurikuler sangat penting untuk dilakukan secara terprogram, sehingga guru dan pelatih dapat memperbaharui pengetahuan dan keterampilan dalam proses pembinaan prestasi olahraga di sekolah. Pada kegiatan selanjutnya diharapkan Dinas Olahraga Kabupaten, KONI dan berbagai lembaga terkati dapat secara berkala untuk memberikan pelatihan kepada setiap guru dan pelatih cabang olahraga sehingga proses pembinaan prestasi olahraga di sekolah melalui program ekstrakurikuler dapat berjalan dengan lebih baik.

\section{Daftar Referensi}

Asnaldi, A. (2015). Profesionalisme Guru Pendidikan Jasmani di Sekolah Dasar. Sport Science.

Budi, D. R., Agustan, B., Listiandi, A. D., Hidayat, R., Festiawan, R., Hanief, Y. N., Qohhar, W., Setiawan, A., \& Nur, L. (2020). Tennis injury: Analysis and preventions actions among national junior tennis athlete. International Journal of Psychosocial Rehabilitation. https://doi.org/10.37200/IJPR/V24I8/PR280805

Budi, D. R., Hidayat, R., \& Febriani, A. R. (2019). The Application of Tactical Approaches in Learning Handballs. JUARA : Jurnal Olahraga. https://doi.org/10.33222/juara.v4i2.534

Budi, D. R., Kusuma, M. N. H., Syafei, M., \& Stephani, M. R. (2019). The Analysis of Fundamental Movement Skill in Primary School Student in Mountain Range. https://doi.org/10.2991/icsshpe18.2019 .56

Budi, D. R., Syafei, M., Kusuma, M. N. H., Suhartoyo, T., Hidayat, R., \& Listiandi, A. D. (2020). The significance of exercise method on forehand and backhand groundstroke skills improvement in tennis. Jurnal SPORTIF : Jurnal Penelitian Pembelajaran. https://doi.org/10.29407/js_unpgri.v6i1.13920 
GANDRUNG: Jurnal Pengabdian Kepada Masyarakat ISSN: 2721-6136 (Online)

Harsono. (2017). Kepelatihan Olahraga: Teori dan Metodologi. Rosda.

Hidayat, R., Febriani, A. R., Budi, D. R., \& Listiandi, A. D. (2019). Pembinaan Prestasi Tim Sepak Takraw

Putri Jawa Tengah Menuju PON XVIII Tahun 2012 di Riau. Jendela Olahraga. https://doi.org/10.26877/jo.v4i2.3815

Indrayana, B. (2017). Peranan Kepelatihan Olahraga Sebagai Pendidik, Pelatih Dan Pembina Olahraga

Di Sekolah. Jorpres (Jurnal Olahraga Prestasi). https://doi.org/10.21831/jorpres.v13i1.12882

Kamnuron, A., Hidayat, Y., \& Nuryadi, N. (2020). Perbedaan Kepercayaan Diri Pada Siswa yang

Mengikuti Ekstrakurikuler Olahraga. Physical Activity Journal. https://doi.org/10.20884/1.paju.2020.1.2.2394

Kusuma, M. N. H., Syafei, M., \& Budi, D. R. (2019). Biomekanika Olahraga. Unsoed Press.

Qohhar, W., \& Pazriansyah, D. (2019). Pengaruh Model Pembelajaran Kooperatif Tipe Teaching Games

For Understanding (TGFU) Terhadap Peningkatan Hasil Belajar Teknik Dasar Sepakbola.

Physical Activity Journal. https://doi.org/10.20884/1.paju.2019.1.1.1998

Sayfei, M., Budi, D. R., Himawan Kusuma, M. N., \& Listiandi, A. D. (2020). Identifikasi Keberbakatan Menggunakan Metode Australian Sport Search Terhadap Kesesuaian Cabang Olahraga Pada Anak Sekolah Dasar. Physical Activity Journal. https://doi.org/10.20884/1.paju.2020.1.2.2285

Setiawan, A., Yudiana, Y., Ugelta, S., Oktriani, S., Budi, D. R., \& Listiandi, A. D. (2020). Hasil Belajar Pendidikan Jasmani dan Olahraga Siswa Sekolah Dasar: Pengaruh Keterampilan Motorik (Tinggi) dan Model Pembelajaran (Kooperatif). TEGAR: Journal of Teaching Physical Education in Elementary School. https://doi.org/10.17509/tegar.v3i2.24513

Subarkah, F., Sartono, H., \& Saputra, M. Y. (2017). Minat Dan Motif Siswi Mengikuti Ekstrakurikuler Olahraga Futsal Di Kota Bandung. Jurnal Kepelatihan Olahraga, 10(2).

Suparyo. (2017). Pengaruh Pembinaan Ekstrakurikuler dan Ketersediaan Sarana Prasarana Terhadap Pengembangan Olahraga: Studi Pada SMA Negeri Se-Kabupaten Majalengka. Indonesian Journal of Education Management and Administration Review, 1(1).

Syafei, M., Budi, D. R., Listiandi, A. D., Festiawan, R., Kusnandar, K., Nurcahyo, P. J., Stephani, M. R., \& Qohhar, W. (2020). Functional Movement Screening: An Early Detection of The Student Injury Risk in Sport Class. Jurnal Pendidikan Jasmani Dan Olahraga. https://doi.org/10.17509/jpjo.v5i2.25466

UU SKN. (2005). Undang-Undang Republik Indonesia Nomor 3 Tahun 2005. Republik Indonesia.

Yani, A., \& Hasri, R. (2020). Hubungan Panjang Tungkai Dengan Kecepatan Lari 60 Meter Siswa Sekolah Dasar. Physical Activity Journal. https://doi.org/10.20884/1.paju.2020.1.2.2423 